Jurnal Hukum Mimbar Justitia

Fakultas Hukum Universitas Suryakancana

Vol. 6 No. 1 - Juni 2020, hlm. 29-55.

ISSN: 2477-5681 (Cetak), ISSN: 2580-0906 (Online)

Open Access at: https://jurnal.unsur.ac.id/jmi

\title{
KONSEP KEPENTINGAN UMUM DALAM PENGADAAN TANAH \\ DIHUBUNGKAN DENGAN KEPASTIAN HUKUM
}

\author{
RR. Meiti Asmorowati \\ Sekolah Tinggi Hukum Bandung \\ Email: meitiasmorowati@yahoo.com
}

Masuk: Maret 2020

Penerimaan: April 2020

Publikasi: Juni 2020

\begin{abstract}
ABSTRAK
Timbul perdebatan mengenai pemaknaan konsep kepentingan umum. Konsep kepentingan umum berubah, tidak sama/berbeda sehingga tidak jelas, tidak tegas dan tidak baku, baik dalam peraturan-peraturan, menurut pendapat para ahli, dalam putusan pengadilan maupun dalam pelaksanaan pengadaan tanah. Akibat konsep kepentingan umum tersebut ditafsirkan lain yaitu ditafsirkan untuk kepentingan swasta, bisnis (komersial) dan pemodal dalam rangka untuk mencari keuntungan yang sebesar-besarnya. Pendekatan penelitian yg digunakan yaitu yuridis normatif, dengan sifat penelitian deskriptif analitis. Sumber penelitian menggunakan data sekunder terdiri dr bahan hukum primer, sekunder dan tersier. Hasil penelitian pertama konsep kepentingan umum dalam pengadaan tanah, bahwa konsep kepentingan umum yang diatur dalam beberapa peraturan perundang-undangan, menurut pendapat para ahli, putusan pengadilan, dan pelaksanaan pengadaan tanah tidak baku. Konsep kepentingan umum dalam Pasal 1 Angka (6) Undang-Undang No. 2 Tahun 2012 tidak jelas. Untuk itu konsep kepentingan umum dibuatkan baku supaya tidak ditafsirkan lain yaitu ditafsirkan untuk kepentingan bisnis dalam rangka mencari keuntungan. Apabila ditafsirkan untuk kepentingan bisnis maka tidak bermanfaat untuk semua orang, termasuk masyarakat dan negara. Hasil penelitian kedua konsep kepentingan umum dalam pengadaan tanah dihubungkan dengan kepastian hukum, bahwa konsep kepentingan umum yang diatur dalam beberapa peraturan perundang-undangan, menurut pendapat para ahli, putusan pengadilan, dan pelaksanaan pengadaan tanah tidak baku, maka tidak ada kepastian hukum. Konsep kepentingan umum dalam Pasal 1 Angka (6) Undang-Undang No. 2 Tahun 2012 tidak jelas yang pada akhirnya tidak memberikan kepastian hukum. Makna kepastian hukum adalah keteraturan, apa yang diperbolehkan dan apa yang tidak diperbolehkan. Supaya dapat menjamin kepastian hukum, maka konsep kepentingan umum dalam pasal tersebut ditambah unsur kepentingan umum yaitu tidak untuk kepentingan bisnis, sehingga pasal tersebut menjadi kepentingan bangsa, negara, dan masyarakat digunakan sebesar-besarnya untuk kemakmuran rakyat serta tidak untuk bisnis.
\end{abstract}


Kata Kunci : Kepentingan Umum, Pengadaan Tanah, Asas Kemanfaatan.

\begin{abstract}
The debate arises regarding the meaning of the concept of public interest. The concept of public interest changes, not the same/different so it is not clear, not firm and not standard, both in regulations, in the opinion of experts, in court decisions, and the implementation of land acquisition. As a result of the concept of public interest is interpreted differently, namely interpreted in the interests of the private, business (commercial) and financiers to seek maximum profits. The research approach used is juridical normative, with the nature of descriptive-analytical research. The research source uses secondary data consisting of primary, secondary, and tertiary legal materials. The results of the first research are the concept of public interest in land acquisition, that the concept of public interest is regulated in several laws and regulations, in the opinion of experts, court decisions, and implementation of nonstandard land acquisition. The concept of public interest in Article 1 Number (6) of Law No. 2 of 2012 is not clear. For this reason, the concept of public interest is made standard so that it is not interpreted differently, that is, interpreted for business purposes in the context of seeking profit. If interpreted for business purposes, it is not useful for everyone, including the community and the state. The results of the research of the two concepts of public interest in the land acquisition are related to legal certainty, that the concept of public interest is regulated in several laws and regulations, in the opinion of experts, court decisions, and the implementation of nonstandard land acquisition, then there is no legal certainty. The concept of public interest in Article 1 Number (6) of Law No. 2 of 2012 is unclear which ultimately does not provide legal certainty. The meaning of legal certainty is order, what is allowed, and what is not allowed. To guarantee legal certainty, the concept of public interest in the article is added to the element of public interest that is not for business purposes, so that the article is in the interest of the nation, state, and society as much as possible for the prosperity of the people and not for business.
\end{abstract}

Keywords : Public Interest, Land Acquisition, Benefit Principle.

\section{PENDAHULUAN}

Setiap negara memiliki tujuan

nasional yang merupakan bagian dari

cita-cita negara yang bersangkutan.

Peran negara yang utama dalam suatu negara adalah mewujudkan cita-cita dari bangsa itu sendiri yang tercantum disetiap Konstitusi atau UndangUndang Dasar 1945 yang bersangkutan. Cita-cita Bangsa Indonesia tercantum dalam Undang-Undang Dasar 1945 sebagai dasar Konstitusi Negara Republik Indonesia, baik sebelum maupun sesudah diamandemen, 
RR. Meiti Asmorowati

Jurnal Hukum Mimbar Justitia

Vol. 6 No. 1 - Juni 2020

mempunyai semangat yang kuat akan kesejahteraan Warga Negara Indonesia dan membentuk

negara kesejahteraan. $^{1}$

Hal tersebut dapat dilihat dalam Pembukaan UUD 1945 Alinea Ke-4 bahwa tujuan Negara Republik Indonesia yaitu: "Melindungi segenap Bangsa Indonesia dan seluruh tumpah darah Indonesia, memajukan kesejahteraan umum, mencerdaskan kehidupan bangsa, dan ikut melaksanakan ketertiban dunia." Yang memiliki tujuan untuk mewujudkan kesejahteraan, keadilan, keamanan, ketentraman, dan ketertiban bagi seluruh kehidupan bangsa dan Negara, serta menjamin perlindungan hukum yang sama bagi setiap warga negara. ${ }^{2}$ Hukum merupakan suatu alat untuk

1 An An Chandrawulan, 2011, Hukum Perusahaan Multinasional: Liberalisasi Hukum Perdagangan Internasional dan Hukum Penanaman Modal, Alumni, Bandung, hlm. 15.

2 Anita Kamilah dan M. Rendi Aridhayandi, 2015, Kajian Terhadap Penyelesaian Sengketa Pembagian Harta Warisan Atas Tanah Akibat Tidak Dilaksanakannya Wasiat Oleh Ahli Waris Dihubungkan Dengan Buku II Kitab Udang-Undang Hukum Perdata tentang Benda (Van Zaken), Jurnal Wawasan Hukum, Vol. 32 No. 1, Sekolah Tinggi Hukum Bandung, Bandung, hlm. 23. menjalankan sebuah negara melalui kekuasaan. $^{3}$

Negara Indonesia sebagai negara hukum dan bukan berdasarkan pada kekuasaan belaka, ${ }^{4}$ maka dalam menjalankan segala kehidupan bernegara harus sesuai dengan aturan hukum yang berlaku demi terciptanya suatu ketertiban hukum dalam masyarakat. Hal ini sesuai dengan istilah Negara Indonesia sebagai Negara hukum (Rechstaat) yang berdasarkan pada Pancasila. ${ }^{5}$

Hukum sebagai institusi sosial, adalah hukum lebih dari pada suatu sistem peraturan belaka, melainkan juga menjalankan fungsi-fungsi sosial dalam dan untuk masyarakatnya,

3 Dedi Mulyadi dan M. Rendi Aridhayandi, 2015, Putusan Mahkamah Konstitusi Tentang Pemilu Serentak Dihubungkan Dengan Pencegahan Korupsi Politik, Jurnal Hukum Mimbar Justitia, Fakultas Hukum Universitas Suryakancana, Cianjur, hlm. 537.

4 Hilman Nur, 2017, Peluang dan Ancaman Masyarakat Ekonomi ASEAN (MEA) Bagi Perkembangan Hak Kekayaan Intelektual Indonesia, Jurnal Hukum Mimbar Justitia, Vol. 3 No. 2, Fakultas Hukum Universitas Suryakancana, Cianjur, hIm. 161-162.

5 Dedi Mulyadi, 2012, Kebijakan Legislasi tentang Sanksi Pidana Pemilu Legislatif di Indonesia dalam Perspektif Demokrasi, Gramata Publishing, Jakarta, hlm. 19. 
RR. Meiti Asmorowati

Jurnal Hukum Mimbar Justitia

Vol. 6 No. 1 - Juni 2020

seperti mengintegrasikan perilaku dan kepentingan para anggota masyarakat. ${ }^{6}$

Untuk mencapai tujuan negara tersebut, khususnya untuk memajukan atau meningkatkan kesejahteraan/kemakmuran rakyat, maka Pemerintah Indonesia melaksanakan pembangunan. Dalam melaksanakan pembangunan, dilakukan melalui cara pengadaan tanah atau dulu istilahnya pembebasan hak atas tanah (prijsgeving) salah satu cara pengambilan tanah oleh negara, cara yang lain yaitu pencabutan hak atas tanah onteigening). ${ }^{7}$ UndangUndang No. 2 Tahun 2012 Pasal 1 Angka (2) tentang Pengadaan Tanah Bagi Pembangunan Untuk Kepentingan Umum menyatakan pengadaan tanah adalah: "Kegiatan menyediakan tanah dengan cara memberi ganti kerugian yang layak dan adil kepada pihak yang berhak."

6 Dwidja Priyatno dan M. Rendi Aridhayandi, 2016, Resensi Buku (Book Review) Satjipto Rahardjo, IImu Hukum, Bandung: PT. Citra Aditya, 2014, Jurnal Hukum Mimbar Justitia, Vol. II No. 02, Fakultas Hukum Universitas Suryakancana, Cianjur, hlm. 884.

7 Abdurrahman, 1991, Masalah Pencabutan Hak-Hak Atas Tanah dan Pembebasan Tanah di Indonesia, Edisi Revisi, Citra Aditya Bakti, Bandung, hlm. 10.
Dilaksanakan pengadaan tanah, karena hak atas tanah mempunyai fungsi sosial, sebagaimana dalam Pasal 6 UUPA yang menyatakan: "Semua hak atas tanah mempunyai fungsi sosial." Dalam Penjelasan Pasal 6 bahwa: "Hak atas tanah apapun yang ada pada seseorang, tidaklah dapat dibenarkan, bahwa tanahnya itu akan dipergunakan (atau tidak dipergunakan) semata-mata untuk kepentingan pribadinya, apalagi kalau hal itu menimbulkan kerugian bagi masyarakat. Penggunaan tanah harus disesuaikan dengan keadaannya dan sifat daripada haknya, hingga bermanfaat baik bagi kesejahteraan dan kebahagiaan yang mempunyainya maupun bermanfaat bagi masyarakat dan negara.

Fungsi sosial dalam UUPA, bahwa hak atas tanah digunakan harus ada keseimbangan antara kepentingan perorangan dan kepentingan umum. Karena tanah dipakai untuk kepentingan umum maka akan bermanfaat bagi semua orang. Dalam Penjelasan Pasal 2 Huruf (c) UndangUndang No. 12 Tahun 2012 asas kemanfaatan adalah hasil pengadaan 
RR. Meiti Asmorowati

Jurnal Hukum Mimbar Justitia

Vol. 6 No. 1 - Juni 2020

tanah mampu memberikan manfaat secara luas bagi kepentingan masyarakat, bangsa, dan negara. Jadi pengadaan tanah harus memenuhi syarat ada ganti rugi, untuk kepentingan umum dan satu lagi harus berdasarkan undang-undang. Sebagaimana ditentukan dalam Pasal 18 UUPA.

Tanah yang diambil dari masyarakat dengan cara pengadaan tanah harus untuk kepentingan umum, tetapi kenyataannya atau secara das sein menimbulkan permasalahan, yaitu timbul perdebatan mengenai pemaknaan konsep kepentingan umum. Konsep kepentingan umum berubah, tidak sama/berbeda sehingga tidak jelas, tidak tegas dan tidak baku, baik dalam peraturan-peraturan, menurut pendapat para ahli, dalam putusan pengadilan maupun dalam pelaksanaan pengadaan tanah. Akibat konsep kepentingan umum tersebut ditafsirkan lain yaitu ditafsirkan untuk kepentingan swasta, bisnis (komersial) dan pemodal dalam rangka untuk mencari keuntungan yang sebesarbesarnya.
Konsep kepentingan umum menjadi penting, agar tidak terjadi perbedaan penafsiran dalam pelaksanaannya, sehingga harus dibedakan dengan jelas antara pembangunan untuk kepentingan umum dan pembangunan yang tujuannya untuk bisnis hanya mencari keuntungan (profit oriented). Dengan adanya konsep kepentingan umum tersebut maka tidak ada kepastian hukum.

Seharusnya atau secara das sollen konsep kepentingan umum dalam beberapa peraturan, menurut pendapat para ahli, putusan pengadilan dan pelaksanaan pengadaan tanah harus sama/tidak berbeda sehingga jelas, tegas dan baku, untuk menjamin kepastian hukum, sebagaimana tercantum dalam Penjelasan Pasal 2 (d) Undang-Undang No. 2 Tahun 2012. Dalam Penjelasan Pasal 2 (d) tersebut terdapat salah satu asas pengadaan tanah yaitu asas kepastian yang mempunyai makna, tersedianya tanah dalam proses pengadaan tanah untuk pembangunan dan memberikan jaminan kepada pihak yang berhak 
RR. Meiti Asmorowati

Jurnal Hukum Mimbar Justitia

Vol. 6 No. 1 - Juni 2020

untuk mendapatkan ganti kerugian yang layak. Untuk itu konsep kepentingan umum harus jelas untuk menjamin kepastian hukum.

\section{Beberapa}

pelaksanaan

pengadaan tanah di bawah ini yang menunjukan permasalahan konsep kepentingan umum ditafsirkan kepentingan swasta, bisnis (komersial) dan pemodal, untuk mencari keuntungan.

Pembangunan Jalan Tol Soroja dibangun dengan hitung-hitungan bisnis, sehingga tarifnyapun tidak bisa dikatakan murah. Bahkan setiap 2 (dua) tahun tarifnya naik, disesuaikan dengan inflasi. Pembuatan Jalan Tol merupakan bisnis, maka jelas akan mengharapkan keuntungan.

Pembangunan Jalan Tol yang demikian tidak terjangkau oleh masyarakat karena hitungan tarifnya tidak masuk daya beli masyarakat. ${ }^{8}$

\section{Pembangunan Jalan Tol Soroja,} diikuti oleh tiga investor. Total biaya investasi yang dibutuhkan dalam

\footnotetext{
8 Jalan Tol Adalah Bisnis dan Jalan Publik Adalah Kepentingan Rakyat, https://www.kompasiana.com, diakses Jum"at 23 Agustus 2019.
}

pembangunan Jalan Tol Soroja mencapai Rp 1.021 triliun, termasuk biaya pembebasan lahan. $^{9}$

Pembangunan Pembangkit Listrik Tenaga Uap (PLTU) Batang dilakukan pihak swasta PT BPI (Bimasena Power Indonesia). Pemerintah sebagai fasilitator telah memfasilitasi pengadaan tanah bagi pihak swasta. Kebutuhan investor di daerah proyek telah difasilitasi Pemda Kabupaten Batang. ${ }^{10}$ Pada saat berjalan pembebasan lahan bagi pembangunan yang sifatnya untuk kepentingan publik, didanai oleh pemerintah. Namun, karena proses pencairan anggaran cukup sulit, pembebasan lahan pun memakan waktu yang cukup lama. ${ }^{11}$

Berdasarkan permasalahan sebagaimana diuraikan di atas, maka yang menjadi objek penelitian yaitu tentang kepentingan umum, pengadaan tanah dan kepastian

9 Tol soroja ditawarkan lagi ke Investor, https://www.bandungkab.go.id, diakses Jum"at 23 Agustus 2019.

10 AT.Aziz, Masalah Pengadaan Tanah Untuk Pembangunan PLTU Batang, Jurnalbhumi.stpn.ac.id, diakses Rabu, 20 Mei 2020

11 Safrezi Fitra, Pembebasan Lahan Bisa Dilakukan dengan paksa, https://katadata.co.id, diakses Jum'at 23 Agustus 2019. 
RR. Meiti Asmorowati

Jurnal Hukum Mimbar Justitia

Vol. 6 No. 1 - Juni 2020

hukum, sebagaimana terdapat dalam identifikasi masalah pertama, yaitu bagaimanakah konsep kepentingan umum dalam pengadaan tanah identifikasi masalah kedua, yaitu bagaimanakah konsep kepentingan umum dalam pengadaan tanah dihubungkan dengan kepastian hukum. Hal ini perlu diteliti, karena terdapat permasalahan. Permasalahannya yaitu konsep kepentingan umum tidak baku, konsep kepentingan umum ditafsirkan menjadi kepentingan swasta, dalam rangka untuk mencari keuntungan yang sebesar-besarnya, sehingga tidak ada kepastian hukum.

Penelitian ini dilakukan dengan tujuan untuk menemukan secara jelas konsep kepentingan umum dalam pengadaan tanah dan untuk menemukan konsep kepentingan umum dalam pengadaan tanah dihubungkan dengan kepastian hukum. Solusi untuk menyelesaikan permasalahan tersebut akan dianalisis dengan menggunakan teori-teori, konsep-konsep dan asas-asas/prinsipprinsip kepastian hukum sebagai landasan teori, dan sebagai teori pendukungnya yaitu teori pengadaan tanah dan teori kepentingan umum serta kaidah-kaidah yang relevan dengan perundang-undangan yang berkaitan dengan permasalahan yang diteliti.

Dengan identifikasi masalah dalam penelitian ini:

1. Baimanakah konsep kepentingan umum dalam pengadaan tanah?

2. Bagaimanakah konsep kepentingan umum dalam pengadaan tanah dihubungkan dengan kepastian hukum?

\section{METODE PENELITIAN}

Penelitian ini menggunakan pendekatan yuridis normatif (legal research), karena merupakan penelitian hukum yang dilakukan dengan cara meneliti bahan pustaka atau data sekunder sebagai bahan dasar untuk diteliti dengan cara mengadakan penelusuran terhadap peraturanperaturan dan literatur-literatur yang berkaitan dengan permasalahan yang diteliti. $^{12}$

12 Soerjono Soekanto \& Sri Pamudji, 2001, Penelitian Hukum Normatif: Suatu Tinjauan Singkat, Rajawali, Jakarta, hlm. 14. 


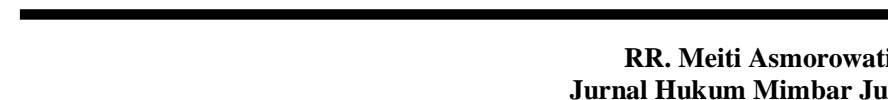

Jurnal Hukum Mimbar Justitia

Vol. 6 No. 1 - Juni 2020

\begin{abstract}
Penelitian yuridis normatif (legal research) merupakan penelitian yang difokuskan untuk mengkaji penerapan kaidah-kaidah atau norma-norma dalam hukum positif yang dilakukan dengan cara mengkaji berbagai aturan hukum yang bersifat formil seperti undang-undang, peraturan presiden serta literatur yang berisi konsepkonsep teoretis kepentingan umum dan pengadaan tanah yang kemudian dihubungkan dengan permasalahan yang akan dibahas. Penelitian ini yang akan dibahas yaitu mengkaji dan menguji secara logis tentang konsep kepentingan umum dalam pengadaan tanah dihubungkan dengan kepastian hukum.
\end{abstract}

Penelitian ini bersifat deskriptif analitis karena penelitian ini menggambarkan dan menganalisis tentang konsep kepentingan umum dalam pengadaan tanah dihubungkan dengan kepastian hukum. Menurut Sunaryati Hartono, penelitian deskriptif analitis, bersifat deskriptif maksudnya dari penelitian ini diharapkan diperoleh gambaran secara rinci dan sistematis tentang permasalahan yang akan diteliti. Analisis dimaksudkan berdasarkan gambaran, fakta yang diperoleh akan dilakukan analisis secara cermat untuk menjawab permasalahan. ${ }^{13}$

Menggunakan tipe penelitian hukum normatif, karena data yang dipergunakan adalah data sekunder. Oleh karena itu penelitian ini dilakukan dengan hanya 1 (satu) tahap, yakni penelitian kepustakaan (Library Research). Penelitian kepustakaan atau penelitian hukum normatif yaitu penelitian dilakukan dengan cara meneliti bahan pustaka. ${ }^{14}$ Dalam penelitian kepustakaan ini jenis data yang digunakan yaitu data sekunder. Data sekunder adalah data yang dipergunakan dalam menjawab permasalahan yang ada dalam penelitian ini melalui studi kepustakaan. $^{15}$ Pengertian studi kepustakaan akan diuraikan di bawah ini dalam metoda/tehnik pengumpulan

13 Sunaryati Hartono 1994, Penelitian Hukum Indonesia Pada Akhir Abad ke-20, Alumni, Bandung, hlm. 101.

14 Soerjono Soekanto \& Sri Pamudji, 2001, Penelitian Hukum Normatif:...Op.Cit., hlm. 15.

15 Ronny Hanitijo Soemitro, 2001, Metode Penelitian Hukum dan Jurimetri, Ghalia Indonesia, Jakarta, hlm. 53. 
RR. Meiti Asmorowati

Jurnal Hukum Mimbar Justitia

Vol. 6 No. 1 - Juni 2020

data. Data sekunder merupakan data utama yang digunakan dalam penelitian ini berupa 3 (tiga) bahan hukum sebagai berikut: ${ }^{16}$

a. Bahan hukum primer merupakan sumber bahan hukum yang bersifat autoritarif artinya mempunyai otoritas. Bahan hukum primer terdiri dari peraturan perundang-undangan, catatan-catatan resmi atau risalah dalam pembuatan peraturan perundang-undangan dan putusan-putusan hakim. Bahan hukum primer dalam penelitian ini yaitu bahan hukum yang mengikat, yang berasal dari UUD 1945, Undang-Undang No. 5

Tahun 1960 tentang Peraturan Dasar Pokok-Pokok Agraria, Undang-Undang No. 2 Tahun 2012 tentang Pengadaan TanahPeraturan Presiden No. 71 Tahun 2012 Jo Peraturan Presiden No. 148 Tahun 2015.

b. Bahan hukum sekunder merupakan bahan hukum yang berupa semua publikasi tentang hukum yang bukan merupakan dokumen-dokumen resmi. Publikasi tentang hukum meliputi buku-buku.

Bahan hukum sekunder yang digunakan dalam penelitian ini yaitu yang relevan dengan hukum yang diangkat dan ditulis dalam penelitian ini yang terdiri dari literatur dan buku-buku, disertasi, jurnal-jurnal hukum, dan makalah hukum agraria serta majalah yang mendukung penulisan ini.

c. Bahan hukum tersier yaitu bahan hukum yang memberikan penjelasan tambahan atau dukungan data yang telah ada pada bahan hukum primer dan bahan hukum sekunder. ${ }^{17}$ Bahan hukum tersier yang digunakan adalah teks, kamus hukum, Kamus Besar Bahasa Indonesia (KBBI), kamus Bahasa Inggris, dan Al-Qur'an.

Selain data sekunder sebagai data utama, juga digunakan data primer sebagai data pendukung wawancara dengan Ibu Susi dari

\footnotetext{
16 Ibid,
} 
RR. Meiti Asmorowati

Jurnal Hukum Mimbar Justitia

Vol. 6 No. 1 - Juni 2020

lembaga legislatif (DPR), Bagian

Pusat Penelitian (Puslit).

Sesuai dengan tahap penelitian ini maka penulis menggunakan teknik pengumpulan data dengan cara studi dokumen dan studi kepustakaan. Studi dokumen, digunakan untuk memperoleh data sekunder dengan membaca, mempelajari, meneliti, mengidenfikasi dan mengalisis data sekunder yang berkaitan dengan materi penelitian. $^{18}$

Studi dokumen yaitu dengan mempelajari permasalahan dari bukubuku, literatur-literatur, disertasi, jurnal, makalah, majalah, kamus hukum dan Kamus Besar Bahasa Indonesia (KBBI), kamus Bahasa Inggris, Al-Qur'an dan bahan-bahan lainnya yang berkaitan dengan materi ditambah lagi dengan kegiatan pencarian data menggunakan internet. Dan studi kepustakaan adalah cara pengumpulan data dengan membaca memahami dan mengutip, merangkum, dan membuat catatan-catatan serta menganalisis peraturan perundang-

18 Soerjono Soekanto, 2007, Pengantar Penelitian Hukum, Cet.III, Universitas Indonesia Press, Jakarta, hlm. 52. undangan. ${ }^{19}$ Perpustakaan

sebagai tempat penelitian dilakukan di Perpustakaan Sekolah Tinggi Hukum Bandung, Perpustakaan Universitas Islam Bandung, Perpustakaan Unpad Pascasarjana Dan Doktoral Komar Kantaatmadja, Perpustakaan Mochtar Kusumaatmadja Unpad, Perpustakaan UGM Yogyakarta, Perpustakaan Pascasarjana UII Yogyakarta, Perpustakaan Fakultas Hukum Undip Semarang. Perpustakaan Badan Pembinaan Hukum Nasional (BPHN), Kantor Pertanahan Kota Bandung. Wawancara dengan Ibu Susi Anggota DPR, Pusat Penelitian DPR Jakarta.

Analisis data adalah merupakan kegiatan dalam penelitian untuk melakukan kajian atau telaah terhadap hasil pengolahan data yang dibantu dengan teori yang telah ditetapkan sebelumnya. ${ }^{20}$ Setelah data penelitian yang diperoleh terkumpul selanjutnya dilakukan analisa dengan menggunakan metode kualitatif yaitu data yang

19 Ronny Hanitijo Soemitro, 2001, Metode Penelitian Hukum dan Jurimetri..., Op. Cit., hlm. 53.

20 Mukti Fajar ND dan Yulianto Achmad, 2000, Dualisme Penelitian Hukum Normatif dan Empiris, Pustaka Pelajar, Yogyakarta, hlm. 183.

\section{7}


RR. Meiti Asmorowati

Jurnal Hukum Mimbar Justitia

Vol. 6 No. 1 - Juni 2020

diperoleh yang mengarah pada kajian yang bersifat teoretis dalam bentuk asas-asas, konsepsi-konsepsi, pandangan-pandangan, doktrin-doktrin hukum dan isi kaidah hukum terlebih dahulu diuraikan secara sistematikal, kemudian dianalisis secara kualitatif.

\section{PEMBAHASAN}

Konsep menurut Kamus Besar Bahasa Indonesia (KBBI), konsep berarti; pengertian, gambaran mental dari objek, proses, pendapat (paham), rancangan (cita-cita) yang telah dipikirkan. ${ }^{21}$ Konsep menurut Rusliana, adalah istilah dan definisi yang digunakan secara abstrak untuk menggambarkan kejadian, kelompok atau individu yang menjadi pusat perhatian. $^{22}$

\section{Konsep yang oleh Soerjono}

Soekanto, didefinisikan sebagai kumpulan dari arti-arti yang berkaitan dengan istilah, biasanya dikaitkan dengan referensi yang bersifat empiris

21 Pusat Pembinaan Bahasa Departemen Pendidikan dan Kebudayaan RI, 1994, Kamus Besar Bahasa Indonesia, Balai Pustaka, Jakarta, hlm. 520.

22 Rusliana, Filsafat Ilmu, 2010, Refika Aditama, Bandung, hlm. 10. di dalam ilmu-ilmu sosial konsep sebaiknya diambil dari teori. Dalam perkembangan disiplin socio legal studies yang menurut pandangan Philipus Mandiri Hadjon, dikatakan sebagai sociological jurisprudence dikaitkan dengan tema utama adalah kesenjangan (the gap) antara law in the books and law in action. Namun demikian studi tersebut hanya sampai pada tingkatan menggambarkan kesenjangan tetapi jarang menjelaskannya (the gap is described but rarely explained). ${ }^{23}$

Konsep ilmu yang dikemukakan

oleh Rudolf Carnap, seperti juga konsep dalam semua kehidupan seharihari, dapat dibagi ke dalam 3 (tiga) golongan, yakni klasifikasi, perbandingan dan kuantitatif. Konsep klasifikasi adalah suatu konsep yang meletakkan obyek yang sedang ditelaah dalam suatu kelas tertentu. Konsep klasifikasi adalah konsep yang paling dikenal oleh semua. Konsep yang lebih efektif dalam memberikan informasi

23 Philipus Mandiri Hadjon dan Tatiek Sri Djatmiati, 2005, Argumentasi Hukum, Cetakan Kedua, UGM Press, Yogyakarta, hlm. 4. 


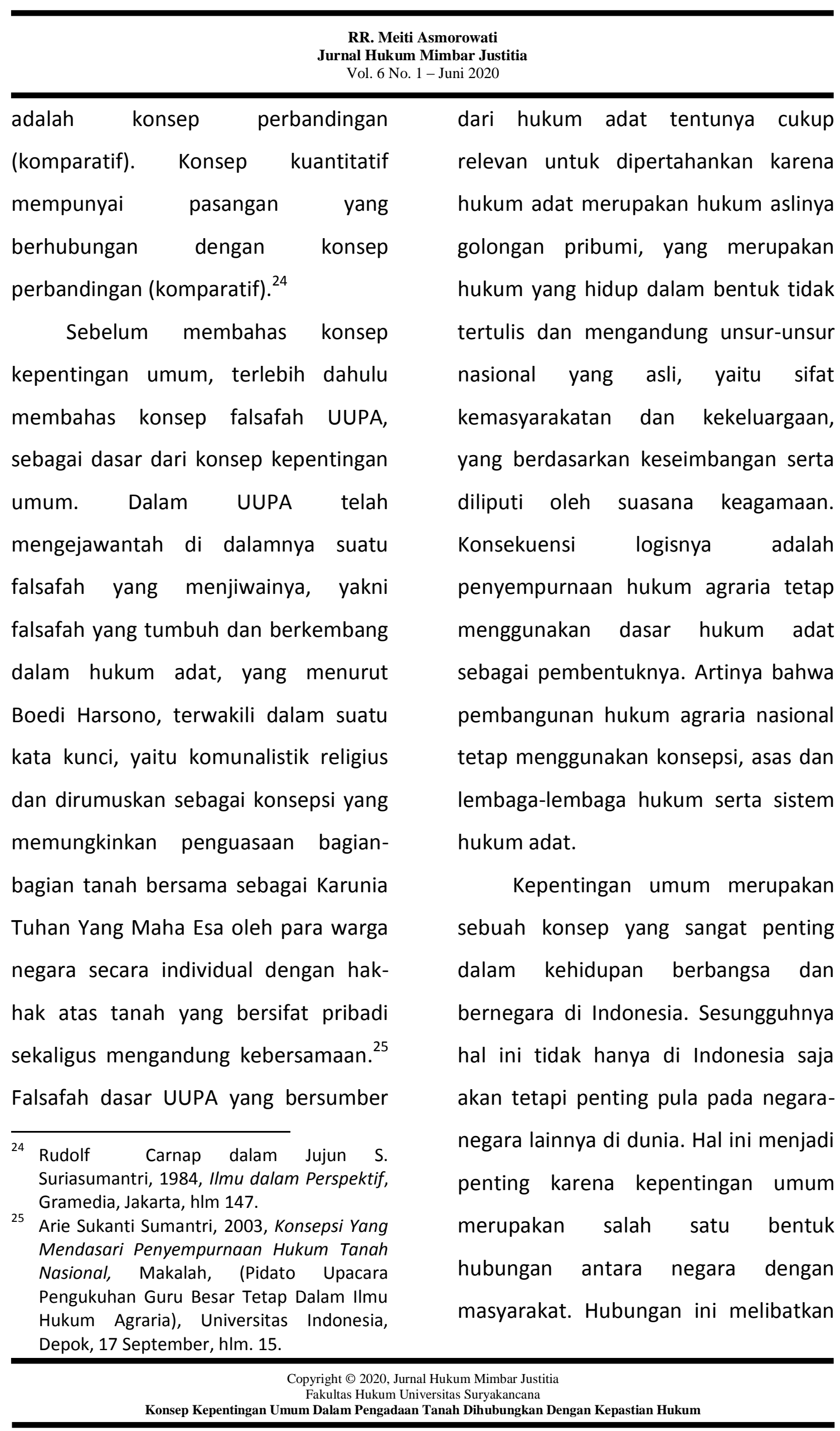


RR. Meiti Asmorowati

Jurnal Hukum Mimbar Justitia

Vol. 6 No. 1 - Juni 2020

hak dan kewajiban negara juga hak dan kewajiban masyarakat selaku warga negara tersebut. Hubungan negara dan masyarakat dalam hal kepentingan umum ini penting untuk dapat didefinisikan dalam kerangka hukum yang baik untuk menjamin hak-hak masyarakat. $^{26}$

Konsep kepentingan umum tidak akan dapat dipahami apabila ditafsirkan secara formal dan tekstual. Konsep kepentingan umum harus dilihat secara substansial dan kontekstual. Penafsiran yang tidak sesuai dengan falsafah dan prinsip dasar UUPA karena perbedaan pilihan kepentingan dan nilai itu dapat ditelusuri dalam berbagai ketentuan peraturan perundang-undangan pertanahan yang terbit sebagai peraturan pelaksanaan UUPA. $^{27}$

Penyempurnaan UUPA bisa diartikan sebagai reposisi UUPA sebagai lex generalis, atau penyempurnaan UUPA sebagai lex specialis karena kekurang lengkapan UUPA dan

26 Merdjono Reksodiputro, 2012, Kepentingan Umum Dalam Hukum Agraria, Penelitian, Komisi Hukum Nasional (KHN), Jakarta, tt.

27 Nurhasan Ismail, 2007, Perkembangan Hukum Pertanahan, Pendekatan Ekonomi Politik, HuMa dan Magister Hukum UGM, Jakarta, hlm. 4. terjadinya penafsiran yang menyimpang dari falsafah dan prinsipprinsip UUPA sebagai akibat dari kecenderungan politik-ekonomi kebijakan makro yang cenderung pro pertumbuhan. Oleh karenanya, dihadapkan pada dua alternatif pilihan itu, saat ini prioritas yang dipilih adalah menyempurnakan UUPA sebagai lex specialis, dengan catatan bahwa pada suatu saat di kemudian hari, dapat disusun suatu undang-undang di bidang sumber daya alam yang bersifat lex generalis, yang akan menjadi platform bersama untuk semua undang-undang sektoral, sehingga dengan demikian akan tercipta hukum di bidang sumber daya alam sebagai satu sistem. ${ }^{28}$

RUU tentang Pertanahan sebagai lex specialis diharapkan dapat menjadi "jembatan antara" untuk meminimalisasi ketidaksinkronan peraturan perundang-undangan sektoral terkait bidang pertanahan. Dalam jangka panjang diharapkan terbentuk undang-undang yang secara komprehensif mengatur tentang

28 Maria Sri Wulan Soemardjono, 2010, Quo vadis UUPA, Harian Umum Kompas, Jakarta, 24 September. 
RR. Meiti Asmorowati

Jurnal Hukum Mimbar Justitia

Vol. 6 No. 1 - Juni 2020

sumberdaya alam sebagai lex generalis yang merupakan perwujudan hukum di bidang sumber daya alam sebagai satu sistem.

Pembentukan Undang-Undang tentang Pertanahan sebagai salah satu upaya penyempurnaan UUPA ditempuh dengan melengkapi dan menjabarkan pengaturan di bidang pertanahan dan menegaskan penafsiran yang tidak sesuai dengan falsafah dan prinsip dasar UUPA. Falsafah UUPA tetap dipertahankan, sedangkan prinsipprinsip dasar UUPA diperkuat dan dikembangkan sesuai dengan prinsip pembaruan agraria.

Falsafah UUPA sesuai dengan Pasal 33 Ayat (3) UUD 1945 menampilkan dua kata kunci yakni bahwa negara sebagai organisasi kekuasaan memperoleh kewenangan dari Bangsa Indonesia untuk menguasai bumi (termasuk tanah), air, dan kekayaan alam yang terkandung di dalamnya, dan bahwa hak menguasai dari negara itu digunakan dengan tujuan untuk tercapainya sebesar-besar kemakmuran rakyat. ${ }^{29}$

Istilah kepentingan umum merupakan suatu konsep yang bersifat begitu umum, yang belum memberikan penjelasan secara lebih spesifik dan terinci untuk operasionalisasinya sesuai dengan makna yang terkandung di dalam istilah tersebut. ${ }^{30}$

Hal ini bisa dilihat dari pasal-pasal yang mengatur tentang kepentingan umum, yang masih dimungkinkan terjadinya tindakan sewenang-wenang dalam menerapkan kepentingan umum, di mana Presiden juga diberi ruang untuk menentukan kepentingan umum tersebut yang memicu munculnya detournement de pavoir (melampaui batas kekuasaan). Detournement de pouvoir adalah suatu perbuatan alat negara/pemerintah yang tidak mempergunakan wewenangnya secara yang tidak sesuai dengan tujuan yang telah diberikan oleh peraturan yang bersangkutan kepada wewenang itu. Konsep

29 www.dpr.go.id.dokumen, hlm. 5, diakses Sabtu 5 Oktober 2019.

30 Oka Mahendra, 1996, Menguak Masalah Hukum: Demokrasi Dan Pertanahan, Pustaka Sinar Harapan, Jakarta, hlm. 279. 
RR. Meiti Asmorowati

Jurnal Hukum Mimbar Justitia

Vol. 6 No. 1 - Juni 2020

kepentingan umum tidak pernah

dirumuskan dengan memadai oleh

hukum positif, hal ini merupakan

konsekuensi dari konsep kepentingan

umum yang tidak dapat didefinisikan

pengertiannya. ${ }^{31}$

Ketua Panitia Khusus Undang-

Undang Pengadaan Tanah Daryatmo

Mardiyanto, mengatakan adanya penjelasan secara spesifik mengenai kriteria kepentingan umum agar tidak terjadi penyalahgunaan pengadaan tanah dengan dalih kepentingan umum. Dalam definisinya, kepentingan umum disebutkan kepentingan umum adalah kepentingan bangsa, negara, dan masyarakat yang harus diwujudkan oleh pemerintah dan digunakan sebesar-besanrnya untuk kemakmuran rakyat. Pengaturan kepentingan umum dalam berbagai peraturan perundangundangan hanyalah ditujukan untuk kepentingan penjajah dan kepentingan

31 Gunanegara, 2008, Rakyat dan Negara Dalam Pengadaan Tanah Untuk Pembangunan Kepentingan Umum: Pelajaran Filsafat, Teori Ilmu dan Jurisprudensi, Tatanusa, Tangerang, hlm. 48. para pengusaha yang mengekploitasi seluruh kekayaan alam. ${ }^{32}$

Dalam rangka untuk memahami konsep kepentingan umum dalam pengadaan tanah, hendaknya perlu dipahami konsep kepentingan umum secara umum. Konsep kepentingan umum memiliki beragam penafsiran yang berbeda. Konsep kepentingan umum secara umum dapat dilihat dalam beberapa regulasi yaitu dalam Penjelasan Pasal 49 huruf (b) UndangUndang No. 5 Tahun 1986 tentang Peradilan Tata Usaha Negara sebagaimana telah diubah dengan Undang-Undang No. 9 Tahun 2004, menyatakan bahwa konsep kepentingan umum meliputi:

1. Kepentingan bangsa dan negara dan/atau;

2. Kepentingan masyarakat bersama dan/atau; dan

3. Kepentingan pembangunan, sesuai dengan peraturan perundang-undangan yang berlaku.

32 Adrian Sutedi, 2007, Implementasi Prinsip Kepentingan Umum di dalam Pengadaan Tanah untuk Pembangunan, Sinar Grafika, Jakarta, hlm. 7. 


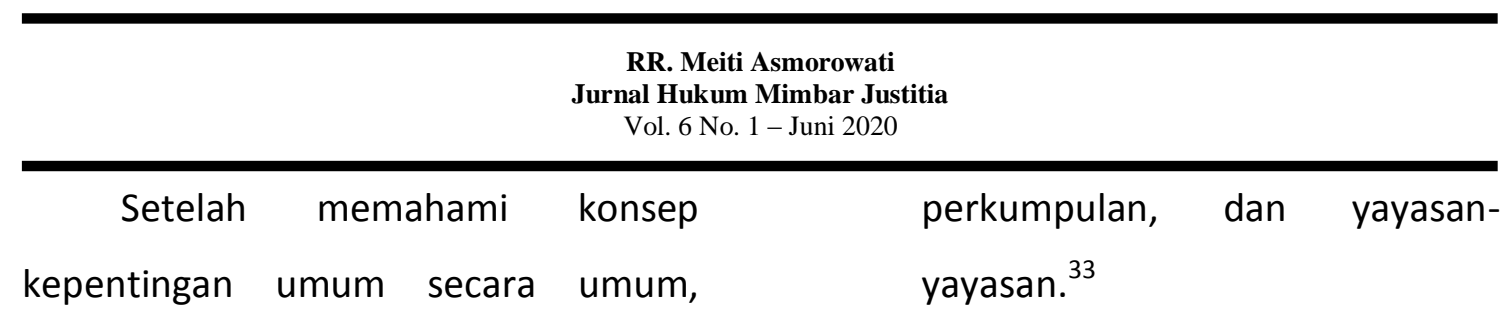

maka perlu dipahami konsep

Setelah mempunyai undangkepentingan umum dalam pengadaan tanah. Konsep kepentingan umum dalam pengadaan tanah diatur dalam regulasi mulai dari peraturan perundang-undangan peninggalan zaman Hindia Belanda sampai dengan sekarang.

Konsep kepentingan umum dalam pengadaan tanah berdasarkan peraturan peninggalan zaman Hindia Belanda diatur dalam dalam S. 1920 No. 574 tentang Onteigenings Ordonantie (pendaftaran tanah), Pasal 1 dan 2 disebutkan konsep kepentingan umum tidak secara tegas dicantumkan konsep kepentingan umum, dalam kedua pasal tersebut yaitu Pasal 1 dan 2 hanya menyebutkan:

1. Untuk kepentingan masyarakat;

2. Untuk kepentingan salah satu bagian dari daerah-daerah otonom; dan

3. Untuk kepentingan orang-orang istimewa, kepentingan pihak swasta, perkumpulanundang nasional di bidang agraria yaitu UUPA, maka konsep kepentingan umum diatur dalam Pasal 18 UUPA. Dalam Pasal 18 UUPA tidak menyebutkan konsep kepentingan umum, tetapi hanya menyebutkan bahwa konsep kepentingan umum meliputi:

1. Kepentingan bangsa dan negara; dan

2. Kepentingan bersama dari rakyat. Pasal tersebut hanya mengatur kategori kepentingan umum saja. Sebagai peraturan pelaksanaan Pasal 18 UUPA, maka diterbitkan beberapa peraturan, yaitu Undang-Undang No. 20 Tahun 1961 tentang Pencabutan Hak-Hak Atas Tanah dan Benda-Benda Yang Berkaitan Dengan Tanah. Dalam Pasal 1 Undang-Undang No. 20 Tahun 1961 konsep kepentingan umum meliputi:

1. Kepentingan bangsa dan negara dan/atau;

33 Aminuddin Salle, 2007, Hukum Pengadaan Tanah Untuk Kepentingan Umum, Total Media, Makasar, hlm. 198. 
RR. Meiti Asmorowati

Jurnal Hukum Mimbar Justitia

Vol. 6 No. 1 - Juni 2020

2. Kepentingan bersama dari rakyat dan/atau

3. Kepentingan pembangunan.

Dalam Instruksi Presiden (Inpres)

No. 9 Tahun 1973 tentang Pelaksanaan

Pencabutan Hak-Hak Atas Tanah dan

Benda-Benda Yang Berkaitan dengan

Tanah konsep kepentingan umum

diatur dalam Pasal 1 Ayat (1) yang menyatakan bahwa konsep

kepentingan umum meliputi:

1. Kepentingan bangsa dan negara, dan/atau;

2. Kepentingan masyarakat luas, dan/atau;

3. Kepentingan rakyat

banyak/bersama dan/atau;

4. Kepentingan pembangunan.

Dalam Inpres No. 9 Tahun 1973

konsep kepentingan umum mengalami perubahan, yaitu kombinasi konsep yang luas dan sempit. Bersifat luas dengan menunjuk pada Pasal 1 Ayat (1) Inpres No. 9 Tahun 1973 dengan hanya menyebutkan empat kriteria kepentingan umum, sedangkan bersifat sempit menunjuk pada objek kepentingan umum dalam Pasal 1 Ayat (2) Inpres No. 9 Tahun 1973 ada 13 kriteria. ${ }^{34}$ Kualifikasi objek kepentingan umum dalam inpres tersebut lebih mementingkan wujud bangunan yang akan diletakkan kepentingan umum, namun tidak mengkualifikasikan hal yang lebih penting, yaitu sejauh mana fungsi kepentingan umum yang lebih konkret. Contohnya gedung sekolah, apakah pasti mempunyai fungsi untuk kepentingan umum, karena biaya untuk pendidikan mahal.

Pemahaman konsep kepentingan umum dalam Undang-Undang No. 20 Tahun 1961 dan Inpres No. 9 Tahun 1973, ternyata baru merupakan sifat kepentingan umum, belum merupakan konsep kepentingan umum. Agar sifat kepentingan umum menjadi suatu konsep kepentingan umum yang sebenarnya, maka harus dikonkretkan, yaitu bahwa suatu proyek pembangunan bersifat kepentingan umum apabila sebelumnya sudah termasuk dalam rencana pembangunan yang telah diberitahukan kepada masyarakat yang bersangkutan dan proyek tersebut sudah harus termasuk dalam rencana induk pembangunan

34 Ibid., hlm. 195. 
RR. Meiti Asmorowati

Jurnal Hukum Mimbar Justitia

Vol. 6 No. 1 - Juni 2020

(RIP) dari daerah yang bersangkutan, serta telah mendapat persetujuan DPRD setempat. RIP tersebut bersifat terbuka untuk umum. ${ }^{35}$

Konsep kepentingan umum dapat dilihat juga dalam beberapa pendapat para ahli yang menunjukkan adanya penafsiran yang berbeda, diantaranya:

1. A.P. Parlindungan, memberikan cacatan bahwa kepentingan umum adalah kepentingan seluruh lapisan masyarakat, tentunya berdampak untuk kepentingan masyarakat luas dan tidak terbatas pada pemerintah saja. ${ }^{36}$

2. Theo Huijbers, menyatakan bahwa: Kepentingan umum (bonum commune) adalah kepentingan masyarakat sebagai keseluruhan yang memiliki ciri-ciri sendiri. Antara lain menyangkut perlindungan hak-hak individu sebagai warga negara, dan menyangkut pengadaan serta

35 Adrian Sutedi, 2007, Implementasi Prinsip Kepentingan Umum..., Op. Cit., hlm. 100.

36 A P.Parlindungan, 1993, Pencabutan dan Pembebasan Hak Atas Tanah Studi Perbandingan, Mandar Maju, Bandung, hlm. 54. pemeliharaan sarana publik dan pelayanan publik. ${ }^{37}$

3. Van Poelje, memberikan makna konsep kepentingan umum sebagai kepentingan masyarakat luas yang harus dilaksanakan oleh pemerintah melalui kebijaksanaan pemerintah. ${ }^{38}$

4. Imam

Koeswahyono, kepentingan umum adalah suatu upaya pemenuhan kebutuhan dengan suatu tujuan untuk masyarakat atau khalayak. ${ }^{39}$

5. Lemaire, istilah kepentingan umum disebut dengan

Bestuurzorg yang berarti tugas dalam fungsi menyelenggarakan kepentingan umum.

6. Schenk, sebagimana dikutip Muchsan memaknai konsep

37 Theo Huijbers, 1995, Filsafat Hukum, Kanisius, Yogyakarta, hlm. 287.

38 Muchsan, 1997, Perbuatan Pemerintah dalam Memperoleh Tanah Untuk Kepentingan Umum, Disertasi, Program Pascasarjana UGM, Yokyakarta, hlm. 43.

39 Imam Koeswahyono, 2013, Kebijakan Kelembagaan Pengadaan Tanah; Perspektif IImu Hukum, Makalah disampaikan pada Seminar Kebijakan Kelembagaan Pengadaan Tanah diselenggarakan oleh Pusat Penelitian dan Pengembangan Badan Pertanahan Nasional (Puslitbang BPN-RI), Senin 09 Desember di Hotel Atmani, Jakarta, hlm. 3. 
RR. Meiti Asmorowati

Jurnal Hukum Mimbar Justitia

Vol. 6 No. 1 - Juni 2020

kepentingan umum sebagai
kepentingan yang lebih banyak
memberikan manfaat dari pada
kerugian
timbul. ${ }^{40}$ Maksudnya manfaat
yang diberikan dapat dinikmati
oleh masyarakat, meskipun
menimbulkan kerugian bagi
beberapa individu.

7. Van Wijk, memberikan pengertian kepentingan umum adalah tuntutan hukum masyarakat yang harus dilayani oleh pemerintah, demi terwujudnya kesejahteraan hidup masyarakat. $^{41}$

8. Julius Stone, konsep kepentingan $\begin{array}{lr}\begin{array}{l}\text { umum adalah } \\ \text { keseimbangan } \\ \text { kepentingan } \\ \text { masyarakat, penguasa } \\ \text { negara. }{ }^{42}\end{array} & \\ & \end{array}$

Hal ini tidak berarti kepentingan umum melawan kepentingan individu. Oleh pemikir Reinach, dikatakan bahwa

40 Muchsan, 1997, Perbuatan Pemerintah dalam Memperoleh Tanah..., Op. Cit., hlm. 43.

41 Ibid., hlm. 44.

42 Bernhard Limbong, 2012, Pengadaan Tanah Untuk Pembangunan, Margaretha Pustaka, hlm. 146.

$\begin{array}{lrr}\text { hukum tidak } & \text { hanya menjamin } \\ \text { kepentingan } & \text { umum, } & \text { tetapi } \\ \text { mengimbangi } & \text { kepentingan } & \text { umum }\end{array}$
dengan kepentingan individual. ${ }^{43}$ Konsep kepentingan umum dapat dilihat juga dalam beberapa putusan pengadilan yang menunjukkan adanya penafsiran yang berbeda.

Putusan pengadilan dalam pelaksanaan pencabutan hak atas tanah Hotel Yen Pin dan Shoping Center di Komplek Yen Pin Jakarta dengan Keputusan Presiden Tanggal 6 Januari 1970 No. 2 Tahun 1970 tentang Pencabutan Hak Atas Tanah dan BendaBenda di Atasnya Yang Terletak di Bagian Kecamatan Taman Sari Jakarta, terdapat beberapa persoalan hukum. ${ }^{44}$ Persoalan pencabutan hak tersebut antara lain persoalan konsep kepentingan umum. Dalam gugatannya, para Penggugat menyatakan bahwa Surat Keputusan Gubernur DKI Jakarta Nomor 11/9/25/1969 tersebut merupakan suatu pencabutan (onteigening) hak atas tanah dan

43 Theo Huijbers, 1995, Filsafat Hukum..., Op. Cit., hlm. 287.

44 Abdurrahman, 1991, Masalah Pencabutan Hak-Hak Atas Tanah...., Op. Cit., hlm. 17. 
RR. Meiti Asmorowati

Jurnal Hukum Mimbar Justitia

Vol. 6 No. 1 - Juni 2020

benda-benda yang ada di atasnya, tetapi dilakukan tanpa memenuhi persyaratan yang telah ditentukan Pasal 6 Undang-Undang No. 20 Tahun 1961. Para Penggugat juga menyatakan pencabutan hak atas tanah tidak memenuhi Pasal 6 yaitu hanya boleh dilakukan dalam keadaan yang memaksa dan untuk kepentingan umum.

Putusan kasus Soritoan Harahap berhadapan dengan Yayasan Pulo Mas CS, No. 1631K/Sip/1974. Soritoan Harahap menggugat Yayasan Pulo Mas sebagai Tergugat I dan Pemerintah RI cq Gubernur DKI Jakarta cq Walikota Jakarta Timur sebagai Tergugat II, bahwa pembangunan perumahan bukan untuk kepentingan umum, karena perumahan akan dijual untuk mendapatkan keuntungan, jadi pembangunan perumahan bukan untuk kepentingan umum, tetapi untuk kepentingan swasta, bisnis (komersial dan pemodal.

Tanah dalam Wilayah Negara Republik Indonesia merupakan salah satu sumber daya alam utama, bagi kelangsungan hidup dan penghidupan bangsa sepanjang masa dalam mencapai sebesar-besarnya kemakmuran rakyat yang terbagi secara adil dan merata. Maka tanah adalah untuk diusahakan atau digunakan untuk kebutuhan nyata. Sehubungan dengan itu penyediaan, peruntukan, penguasaan, penggunaan dan pemeliharaannya perlu diatur agar terjamin kepastian hukum dalam penguasaan dan pemanfaatannya serta sekaligus terselenggara perlindungan hukum bagi rakyat banyak, dengan tetap mempertahankan kelestarian kemampuannya dalam mendukung pembangunan yang berkelanjutan. ${ }^{45}$

Berdasarkan uraian tersebut maka konsep kepentingan umum tidak baku dan tidak jelas, sehingga tidak ada kepastian hukum. Makna kepastian hukum menurut algra merupakan kepastian mengenai hak dan kewajiban serta mengenai apa yang menurut hukum diperbolehkan dan tidak diperbolehkan. Begitu juga makna kepastian hukum menurut Mochtar

45 Boedi Harsono, 2002, Menuju Penyempurnaan Hukum Tanah Nasional Dalam Hubungannya dengan Tap MPR RI No. IX/MPR/2001, Universitas Trisakti, Jakarta, hlm. 28. 
RR. Meiti Asmorowati

Jurnal Hukum Mimbar Justitia

Vol. 6 No. 1 - Juni 2020

Kusumaatmadja dan Arief Sidharta, kepastian hukum adalah untuk mencapai keteraturan dalam kehidupan manusia dalam masyarakat. Jika aturan konsep kepentingan umum dirumuskan secara tidak jelas, maka tidak dapat memenuhi kepastian hukum diperlukan dalam menentukan konsep kepentingan umum yang jelas dan baku supaya tidak ditafsirkan lain.

Konsep kepentingan umum dapat menimbulkan ketidakpastian hukum dalam pelaksanaannya, sehingga menjadi tidak jelas antara pembangunan untuk kepentingan umum dan untuk kepentingan swasta, bisnis (komersil) dan pemodal, misalnya apakah rumah sakit yang didirikan oleh pemerintah kemudian dikelola oleh pihak swasta termasuk katagori kepentingan umum atau tidak, padahal rumah sakit tersebut dalam praktiknya tidak lagi melakukan pelayanan kesehatan yang bersifat sosial, akan tetapi mencari keuntungan. Contoh lain pembangunan rumah yang didirikan oleh pemerintah yang dikelola oleh pihak swasta, termasuk kategori kepentingan umum atau tidak, karena rumah tersebut dijual untuk mencari keuntungan. Demikian pula jalan tol, bandara, pelabuhan, terminal yang dikelola oleh pihak BUMN atau pihak swasta tujuannya adalah mencari keuntungan. Rumah sakit, perumahan dan jalan tol termasuk dalam Pasal 10 termasuk objek kepentingan umum, tetapi tujuan dari pembangunan rumah sakit dan perumahan sudah berbeda dengan tujuannya, yaitu bukan untuk kepentingan umum tetapi untuk kepentingan bisnis dalam rangka mencari keuntungan. Sehingga konsep kepentingan umum yang tidak memenuhi Pasal 10 tidak menjamin kepastian hukum.

Peneliti berpendapat bahwa konsep kepentingan umum bukanlah sesuatu yang tidak dapat didefinisikan atau tidak dapat dirumuskan. Alasan penulis adalah bahwa konsep kepentingan umum yang memenuhi kepastian hukum dirumuskan dengan mengambil pendapat dari teori Maria Sri Wulan Soemardjono, yaitu memenuhi salah satu unsur kepentingan umum yang menyebutkan dilakukan untuk non profit/bukan 
RR. Meiti Asmorowati

Jurnal Hukum Mimbar Justitia

Vol. 6 No. 1 - Juni 2020

untuk bisnis. Berdasarkan konsep kepentingan umum yang memenuhi unsur kepentingan umum untuk non profit/bukan untuk bisnis, maka berdasarkan hal tersebut dapat dibuat definisi atau dirumuskan konsep kepentingan umum yang baku, tidak dapat ditafsirkan lain. Konsep kepentingan umum yang sudah memenuhi unsur kepentingan umum yang dikemukakan Maria Sri Wulan Soemardjono, maka dapat dikatakan konsep kepentingan umum, bukan kepentingan swasta, bisnis (pemodal) dan investor. Dari konsep kepentingan umum tersebut, dapat ditemukan penegasan bahwa konsep kepentingan umum harus memenuhi salah satu unsur dari teori kepentingan umum yang dikemukakan oleh Maria Sri Wulan Soemardjono yaitu tidak untuk kepentingan bisnis.

Konsep kepentingan umum yang tercantum dalam Pasal 1 Angka (6) Undang-Undang No. 2 Tahun 2012 merupakan konsep yang tidak pasti dan tidak baku, dalam undang-undang hanya disebutkan kegiatan-kegiatan pembangunan untuk kepentingan umum, tanpa memberikan batasan yang jelas, sehingga dalam pelaksanaannya terjadi perbedaan penafsiran mengenai apa yang disebut sebagai kepentingan umum. Rumusan Pasal 1 Angka (6) dengan tidak ada batasan yang jelas konsep kepentingan umum, baik dalam peraturanperaturan, pendapat para ahli, putusan pengadilan dan dalam pelaksanaan pengadaan tanah, telah terjadi manipulasi kepentingan umum, dengan alasan untuk kepentingan umum, tanah masyarakat dapat dibebaskan oleh pemerintah, padahal dalam kenyataanya bukan untuk kepentingan umum, akan tetapi untuk kepentingan bisnis. Idealnya, rumusan undangundang harus lengkap dan jelas sehingga tidak perlu ditafsirkan. Akan tetapi, rumusan undang-undang yang jelas dan lengkap cenderung bersifat kasuistis, sehingga tidak akan mudah mengikuti perkembangan keadaan dan tidak akan bertahan dalam kurun waktu yang lama ${ }^{46}$

46 Sudikno Mertokusumo, 2010, Mengenal
Hukum: Suatu Pengantar, Liberty,
Yogyakarta, hlm. 72. 


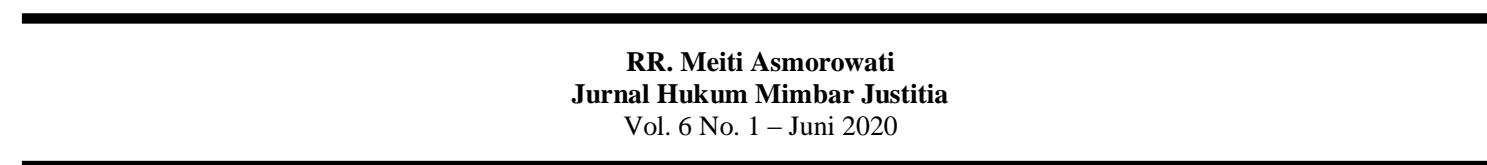

Untuk itu konsep kepentingan umum yang tercantum dalam Pasal 1 Angka (6) Undang-Undang No. 2 Tahun 2012 perlu penegasan dengan menambah unsur/kriteria dari konsep kepentingan umum mengambil dari salah satu teori yaitu sebagaimana yang dikemukakan dalam teori unsur kepentingan umum dari Maria Sri Wulan Soemardjono yaitu tidak boleh untuk profit/bisnis. Konsep kepentingan umum yang asalnya dalam Pasal 1 Angka (6) yang menyatakan kepentingan umum adalah kepentingan bangsa, negara, dan masyarakat yang harus diwujudkan oleh pemerintah dan digunakan sebesar-besarnya untuk kemakmuran rakyat. Jadi konsep kepentingan umum yang pasti adalah kepentingan bangsa, negara, dan masyarakat digunakan sebesarbesarnya untuk kemakmuran rakyat serta tidak boleh untuk bisnis. Aturan konsep kepentingan umum tersebut sudah jelas dan baku, sehingga menjamin kepastian hukum.

Penegasan konsep kepentingan umum yang akan menjadi dasar dan kriterianya perlu ditentukan secara tegas sehingga pengambilan tanahtanah (pengadaan tanah) dimaksud benar-benar sesuai dengan landasan hukum yang berlaku. ${ }^{47}$ Begitu juga dengan adanya Undang-Undang No. 2 Tahun 2012 sudah memberikan kepastian hukum karena syarat dalam Pasal 18 UUPA bahwa pengadaan tanah pengaturannya harus berbentuk undang-undang sudah tercapai, sehingga sudah menjamin kepastian hukum. Dengan tetap memperhatikan hal-hal tersebut diharapkan perbedaan penafsiran dalam memahami konsep kepentingan umum dalam pengadaan tanah dapat berkurang.

\section{PENUTUP}

\section{A. Kesimpulan}

1. Konsep kepentingan umum dalam pengadaan tanah, bahwa konsep kepentingan umum yang diatur dalam beberapa peraturan perundang-undangan, menurut pendapat para ahli, putusan pengadilan, dan pelaksanaan pengadaan tanah tidak baku. Konsep kepentingan umum dalam Pasal 1 Angka (6) Undang-

\footnotetext{
47 Abdurrahman, 1991, Masalah Pencabutan Hak-Hak Atas Tanah ...., Op. Cit., hlm. 36.
} 
RR. Meiti Asmorowati

Jurnal Hukum Mimbar Justitia

Vol. 6 No. 1 - Juni 2020

Undang No. 2 Tahun 2012 tidak jelas. Untuk itu konsep kepentingan umum dibuatkan baku supaya tidak ditafsirkan lain yaitu ditafsirkan untuk kepentingan bisnis dalam rangka mencari keuntungan. Apabila ditafsirkan untuk kepentingan bisnis maka tidak bermanfaat untuk semua orang, termasuk masyarakat dan negara.

2. Konsep kepentingan umum dalam pengadaan tanah dihubungkan dengan kepastian hukum, bahwa konsep kepentingan umum yang diatur dalam beberapa peraturan perundang-undangan, menurut pendapat para ahli, putusan pengadilan, dan pelaksanaan pengadaan tanah tidak baku, maka tidak ada kepastian hukum. Konsep kepentingan umum dalam Pasal 1 Angka (6) UndangUndang No. 2 Tahun 2012 tidak jelas yang pada akhirnya tidak memberikan kepastian hukum. Makna kepastian hukum adalah keteraturan, apa yang diperbolehkan dan apa yang tidak diperbolehkan. Supaya dapat menjamin kepastian hukum, maka konsep kepentingan umum dalam pasal tersebut ditambah unsur kepentingan umum yaitu tidak untuk kepentingan bisnis, sehingga pasal tersebut menjadi kepentingan bangsa, negara, dan masyarakat digunakan sebesarbesarnya untuk kemakmuran rakyat serta tidak untuk bisnis.

\section{B. Saran}

1. Diharapkan kepada pembentuk undang-undang untuk menetapkan konsep kepentingan umum yang terdapat dalam Undang-Undang No. 2 Tahun 2012, karena sudah tidak relevan lagi dengan dinamika sosial yang terjadi dimasyarakat.

2. Dalam Undang-Undang tentang Pertanahan diharuskan untuk memberikan kepastian hukum terhadap konsep kepentingan umum yang belum jelas dan baku dalam UUPA maupun dalam Undang-Undang No. 2 Tahun 
RR. Meiti Asmorowati

Jurnal Hukum Mimbar Justitia

Vol. 6 No. 1 - Juni 2020

2012, dalam putusan pengadilan

dan dalam pelaksanaan

pengadaan tanah.

\section{DAFTAR PUSTAKA}

A. Buku.

A P.Parlindungan, 1993, Pencabutan dan Pembebasan Hak Atas Tanah Studi Perbandingan, Mandar Maju, Bandung.

Abdurrahman, 1991, Masalah Pencabutan Hak-Hak Atas Tanah dan Pembebasan Tanah di Indonesia, Edisi Revisi, Citra Aditya Bakti, Bandung.

Adrian Sutedi, 2007, Implementasi Prinsip Kepentingan Umum di dalam Pengadaan Tanah untuk Pembangunan, Sinar Grafika, Jakarta.

Aminuddin Salle, 2007, Hukum Pengadaan Tanah Untuk Kepentingan Umum, Total Media, Makasar.

An An Chandrawulan, 2011, Hukum Perusahaan Multinasional: Liberalisasi Hukum Perdagangan Internasional dan Hukum Penanaman Modal, Alumni, Bandung.

Bernhard Limbong, 2012, Pengadaan Tanah Untuk Pembangunan, Margaretha Pustaka.

Boedi Harsono, 2002, Menuju Penyempurnaan Hukum Tanah
Nasional Dalam Hubungannya dengan Tap MPR RI No. IX/MPR/2001, Universitas Trisakti, Jakarta.

Dedi Mulyadi, 2012, Kebijakan Legislasi tentang Sanksi Pidana Pemilu Legislatif di Indonesia dalam Perspektif Demokrasi, Gramata Publishing, Jakarta.

Gunanegara, 2008, Rakyat dan Negara Dalam Pengadaan Tanah Untuk Pembangunan Kepentingan Umum: Pelajaran Filsafat, Teori Ilmu dan Jurisprudensi, Tatanusa, Tangerang.

Merdjono Reksodiputro, 2012, Kepentingan Umum Dalam Hukum Agraria, Penelitian, Komisi Hukum Nasional (KHN), Jakarta.

Mukti Fajar ND dan Yulianto Achmad, 2000, Dualisme Penelitian Hukum Normatif dan Empiris, Pustaka Pelajar, Yogyakarta.

Nurhasan Ismail, 2007, Perkembangan Hukum Pertanahan, Pendekatan Ekonomi Politik, HuMa dan Magister Hukum UGM, Jakarta.

Oka Mahendra, 1996, Menguak Masalah Hukum: Demokrasi Dan Pertanahan, Pustaka Sinar Harapan, Jakarta.

Philipus Mandiri Hadjon dan Tatiek Sri Djatmiati, 2005, Argumentasi Hukum, Cetakan Kedua, UGM Press, Yogyakarta.

Pusat Pembinaan Bahasa Departemen Pendidikan dan Kebudayaan RI, 
RR. Meiti Asmorowati

Jurnal Hukum Mimbar Justitia

Vol. 6 No. 1 - Juni 2020

1994, Kamus Besar Bahasa

Indonesia, Balai Pustaka, Jakarta.

Ronny Hanitijo Soemitro, 2001, Metode Penelitian Hukum dan Jurimetri, Ghalia Indonesia, Jakarta.

Rudolf Carnap dalam Jujun $S$. Suriasumantri, 1984, IImu dalam Perspektif, Gramedia, Jakarta.

Rusliana, Filsafat IImu, 2010, Refika Aditama, Bandung.

Soerjono Soekanto \& Sri Pamudji, 2001, Penelitian Hukum Normatif: Suatu Tinjauan Singkat, Rajawali, Jakarta.

Soerjono Soekanto, 2007, Pengantar Penelitian Hukum, Cet.III, Universitas Indonesia Press, Jakarta.

Sudikno Mertokusumo, 2010, Mengenal Hukum: Suatu Pengantar, Liberty, Yogyakarta.

Sunaryati Hartono 1994, Penelitian Hukum Indonesia Pada Akhir Abad ke-20, Alumni, Bandung.

Theo Huijbers, 1995, Filsafat Hukum, Kanisius, Yogyakarta.

\section{B. Peraturan Perundang-Undangan.}

Undang-Undang Dasar Negara Republik Indonesia Tahun 1945.

UUD Sementara 1950.
Undang-Undang No. 5 Tahun 1960 tentang Peraturan dasar PokokPokok Agraria.

Undang-Undang No. 2 Tahun 2012 tentang Pengadaan Tanah Bagi Pembangunan Untuk Kepentingan Umum.

Ketetapan Majelis Permusyawaratan Rakyat Republik Indonesia No. IX/MPR/2001 tentang Pembaruan Agraria dan Pengelolaan Sumber Daya Alam.

Peraturan Presiden No. 40 Tahun 2014 tentang Perubahan Atas Peraturan Presiden No. 71 Tahun 2012 tentang Penyelenggaraan Pengadaan Tanah bagi Pembangunan untuk Kepentingan Umum.

Peraturan Presiden No. 99 Tahun 2014 tentang Perubahan Kedua Atas Peraturan Presiden No. 71 Tahun 2012 tentang Penyelenggaraan Pengadaan Tanah bagi Pembangunan untuk Kepentingan Umum.

Peraturan Presiden No. 30 Tahun 2015 tentang Perubahan Ketiga Atas Peraturan Presiden No. 71 Tahun 2012 tentang Penyelenggaraan Pengadaan Tanah bagi Pembangunan untuk Kepentingan Umum.

Peraturan Presiden No. 148 Tahun 2015 tentang Perubahan Atas Peraturan Presiden No. 71 Tahun 2012 tentang Penyelenggaraan Pengadaan Tanah bagi 


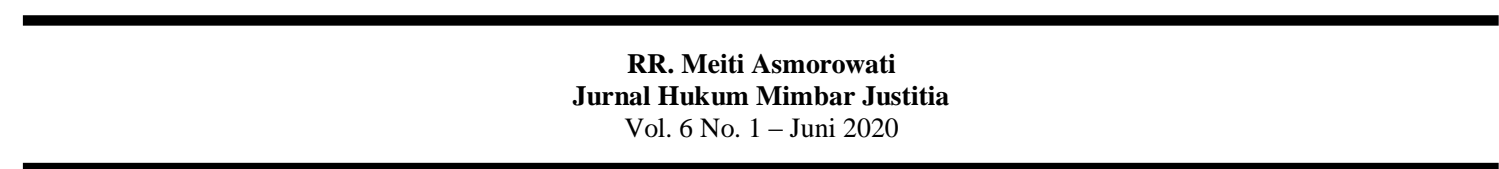

Pembangunan untuk Kepentingan Umum.

Peraturan Presiden No. 17 Tahun 2015 tentang Kementerian Agraria dan tata Ruang.

Peraturan Presiden No. 71 Tahun 2012 tentang Pengadaan Tanah Bagi Pembangunan Untuk Kepentingan Umum.

Permenagta/Kepala BPN No. 5 Tahun 2015 tentang Petunjuk Teknis Pelaksanaan Pengadaan Tanah.

Permenagta/Kepala BPN No. 6 Tahun 2015 tentang Perubahan Permenagta/Kepala BPN No. 5 Tahun 2015 tentang Petunjuk Teknis Pelaksanaan Pengadaan Tanah.

Peraturan Menteri Dalam Negeri No. 72 Tahun 2012 tentang Biaya Operasional dan Biaya Pendukung Penyelenggaraan Pengadaan Tanah bagi Pembangunan untuk Kepentingan Umum yang Bersumber dari Anggaran Pendapatan dan Belanja Daerah.

\section{Jurnal, Disertasi, Pidato}

\section{Pengukuhan Guru Besar,} Seminar, Internet.

Anita Kamilah dan M. Rendi Aridhayandi, 2015, Kajian Terhadap Penyelesaian Sengketa Pembagian Harta Warisan Atas Tanah Akibat Tidak Dilaksanakannya Wasiat Oleh Ahli Waris Dihubungkan Dengan
Buku II Kitab Udang-Undang Hukum Perdata tentang Benda (Van Zaken), Jurnal Wawasan Hukum, Vol. 32 No. 1, Sekolah Tinggi Hukum Bandung, Bandung. Arie Sukanti Sumantri, 2003, Konsepsi Yang Mendasari Penyempurnaan Hukum Tanah Nasional, Makalah, (Pidato Upacara Pengukuhan Guru Besar Tetap Dalam IImu Hukum Agraria), Universitas Indonesia, Depok, 17 September.

AT. Aziz, Masalah Pengadaan Tanah Untuk Pembangunan PLTU Batang, Jurnalbhumi.stpn.ac.id, diakses Rabu, 20 Mei 2020.

Dedi Mulyadi dan M. Rendi Aridhayandi, 2015, Putusan Mahkamah Konstitusi Tentang Pemilu Serentak Dihubungkan Dengan Pencegahan Korupsi Politik, Jurnal Hukum Mimbar Justitia, Fakultas Hukum Universitas Suryakancana, Cianjur.

Dwidja Priyatno dan M. Rendi Aridhayandi, 2016, Resensi Buku (Book Review) Satjipto Rahardjo, Ilmu Hukum, Bandung: PT. Citra Aditya, 2014, Jurnal Hukum Mimbar Justitia, Vol. II No. 02, Fakultas Hukum Universitas Suryakancana, Cianjur.

Hilman Nur, 2017, Peluang dan Ancaman Masyarakat Ekonomi ASEAN (MEA) Bagi Perkembangan Hak Kekayaan Intelektual Indonesia, Jurnal Hukum Mimbar Justitia, Vol. 3 No. 2, Fakultas Hukum 
RR. Meiti Asmorowati

Jurnal Hukum Mimbar Justitia

Vol. 6 No. 1 - Juni 2020

Universitas Suryakancana,

Cianjur.

Imam Koeswahyono, 2013, Kebijakan

Kelembagaan Pengadaan Tanah;

Perspektif IImu Hukum, Makalah

disampaikan pada Seminar

Kebijakan Kelembagaan

Pengadaan Tanah

diselenggarakan oleh Pusat

Penelitian dan Pengembangan

Badan Pertanahan Nasional

(Puslitbang BPN-RI), Senin 09

Desember di Hotel Atmani, Jakarta.

Jalan Tol Adalah Bisnis dan Jalan Publik Adalah Kepentingan Rakyat, https://www.kompasiana.com, diakses Jum"at 23 Agustus 2019.

Maria Sri Wulan Soemardjono, 2010, Quo vadis UUPA, Harian Umum Kompas, Jakarta, 24 September.

Muchsan, 1997, Perbuatan Pemerintah dalam Memperoleh Tanah Untuk Kepentingan Umum, Disertasi, Program Pascasarjana UGM, Yokyakarta.

Safrezi Fitra, Pembebasan Lahan Bisa Dilakukan dengan paksa, https://katadata.co.id, diakses Jum'at 23 Agustus 2019.

Tol soroja ditawarkan lagi ke Investor, https://www.bandungkab.go.id, diakses Jum"at 23 Agustus 2019.

www.dpr.go.id.dokumen, hlm. 5, diakses Sabtu 5 Oktober 2019. 